\title{
A Field Survey to Investigate The Flora and Fauna of Dhauladhar Nature Park in North-Western Himalayan Region of India
}

\author{
Neeraj Kumar Sharma ${ }^{1}$
}

${ }^{1}$ Zoology, Govt. Degree College Nagrota Bagwan, Himachal Pradesh-176047

\section{ABSTRACT}

Taxonomic studies on wildlife biodiversity has always been very fascinating along with great purpose of providing valuable information of their present status with regard to species number and future course of action required for their conservation. A study regarding survey of flora and fauna was carried out at Dhauladhar Nature's Park of Gopalpur in district Kangra of Himachal Pradesh during the month of April, 2015. The present study has revealed the presence of 9 mammals, 2 reptilians, 5 pheasants and 4 other birds belonging to 12 families along with 44 plants species belonging to 28 families. Further, it is suggested that provisions for Himalayan snakes and butterflies, the other two are very important Himalayan fauna which could be created as soon as possible so that nature's park can fulfill its true purpose of conservation of Himalayan wild animals in real sense.

Keywords: fauna, flora, Nature Park, wild life biodiversity

\section{INTRODUCTION}

The idea of protection and preservation of wildlife has been an integral part of our religion and culture ethos since the ancient times. Our Vedic hymns and mythology is in full praise of animals and depicting many of them as God. Wildlife in layman's language refers to magnificent animals and birds in their natural habitats such as jungles, deserts, grasslands etc. However, scientifically it includes both animals and plants in their wilderness. Neutral diversity theories predict that species number and immigration rates are sufficient to predict animal and plant community abundance distributions [1-3].

As far as the northwestern Himalayan flora and fauna is concerned it is mainly affected by climatic conditions and altitude. Which is mainly responsible for wide spectrum of species, however in past few decade factors like haunting [4], forest fire, destruction of habitats due to development works, deforestation, pollution and cleanliness, introduction of exotic species, construction of new highways, physical alteration of environment, lack of environment sensitivity and official laxity have been mainly responsible to be a great threat to wild life. Few authors have dared to

${ }^{*}$ Corresponding author:

Neeraj Kumar Sharma

Zoology, Govt. Degree College Nagrota Bagwan,

Himachal Pradesh-176047, India

E-mail: Sharma.neeraj.neeraj03@gmail.com document the declines in the number of components of biodiversity [5-7].

Therefore, the continuous rising in the number of endangered species list have necessitated in present time to speed up our efforts for the protection and management of wild life on a much larger scale and faster rate. A number of initiatives have been taken up in this direction for the benefit of wildlife. The Indian Board for Wildlife (IBWL) has been established as far

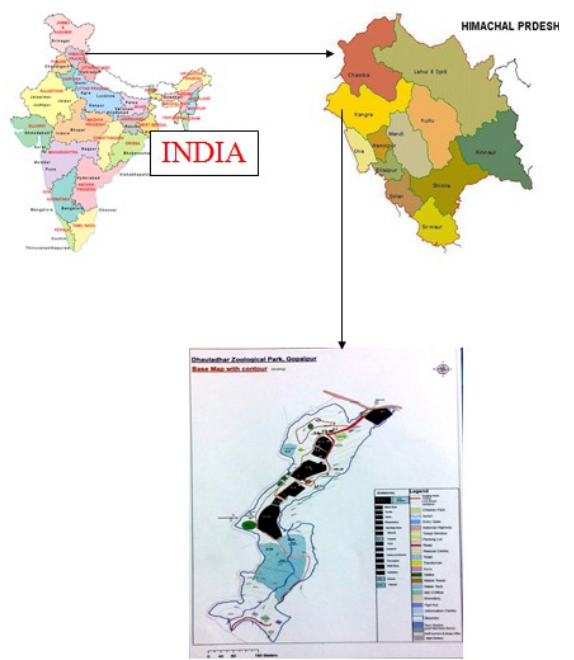

Figure 1. Location map of Dhauladhar Nature Park at Gopalpur in District Kangra of Himachal Pradesh (Source: Wild life Division Hamirpur, Himachal Pradesh) 


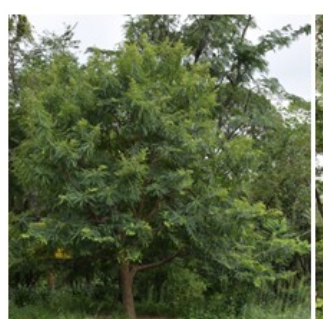

Emblica officinalis

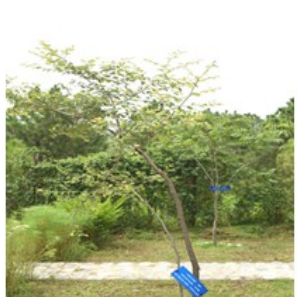

Ziziphus jujuba

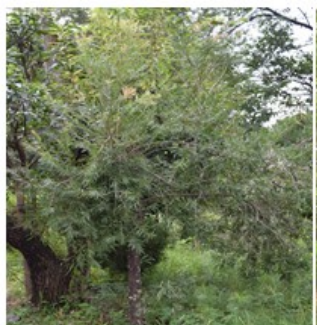

Callistemon lancelatus

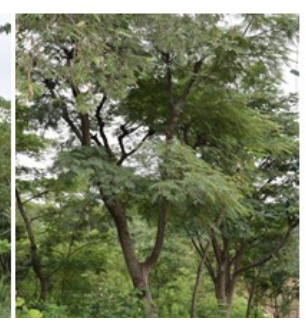

Albizia stipulata

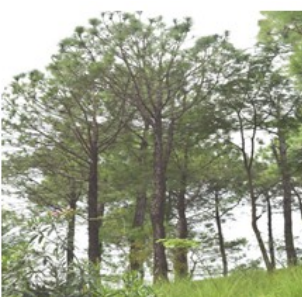

Pinus roxburghii

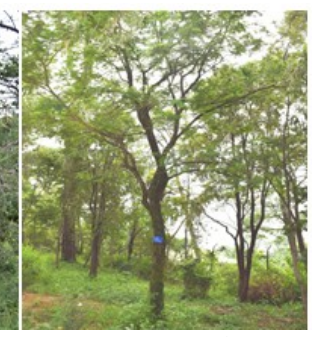

Acacia catechu
Figure 2. Photographs of Flora recorded in Dhauladhar Nature Park Gopalpur in western Himalayan region, Himachal Pradesh (India).

as in the year 1952 to manage and look after the country's wildlife. Since 1955, wildlife week is observed every year to educate people about the importance and need for the protection of wildlife biodiversity. Trade in rare and endangered species has been banned under the wildlife (Protection) Act, 1972. National Parks and Sanctuaries have been setup in different corner of the country under this act for the preservation of wildlife.

Falling in this line the Govt. of Himachal Pradesh has also setup on $23^{\text {th }}$ April, 1992 a nature park in the lap of Dhauladhar range of Himalaya named as "Dhauladhar Nature Park" in Gopalpur (Distt.Kangra) with the aim to sensitize and create awareness among public, rescue and conserve wild animals and to provide opportunity for research. With regards to research studies on biodiversity of Dhauladhar Nature's park is concerned, a beginning has been made by conducting study on birds biodiversity [8]. Therefore, more scientific studies are required so to have a deep insight to better understand the biodiversity of this nature's park.

\section{Study Area}

Dhauladhar Nature Park is located in the mid-hills of the Shivalik ranges of the Himalayas. The Park falls under wild life division of Hamirpur in Himachal Pradesh. Dhauladhar Nature Park is situated at $31^{\circ} 42^{\prime}$ North Latitude and $76^{\circ} 43^{\prime}$ East Longitude, having an altitude varying from 1235 to $1300 \mathrm{~m}$ of $\mathrm{msl}$ in the mid-hill of the northwestern region of Himalayas. It is located at a place known as Gopalpur which is at about $25 \mathrm{~km}$ from Kangra town, about $20 \mathrm{~km}$ from district headquarter Dharamshala, $13 \mathrm{~km}$ from Palampur and $6 \mathrm{~km}$. from famous Chamunda Devi temple in District Kangra of Himachal Pradesh. The study area has been spread over in a land of about 12.5 hectares (Figure 1).

\section{MATERIALS AND METHODS}

In order to know the flora and fauna of the Dhauladhar Nature Park, the undergraduate students in their $4^{\text {th }}$ semester in Zoology (Major) of Govt. Degree College Nagrota Bagwan (Himachal Pradesh) participated in the survey under discussion. The whole area of Dhauladhar Nature Park was divided into 2 sections and a total of 25 students participated in this exercise. The fauna was recorded in toto, while flora of the nature's park was recorded following the Random sampling technique. Further, the flora and fauna present in the Nature's Park were identified with the help of relevant reference and text books. Similar methodology has also been followed while studying the bird's biodiversity of this nature's park [8]. The present

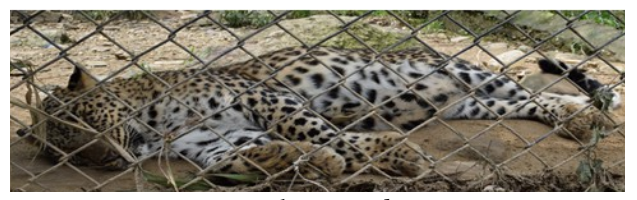

Panthera pardus
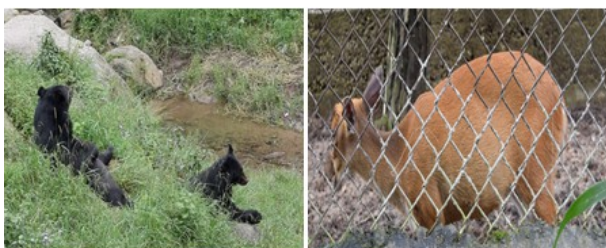

Selenarctos thibetonus

Muntiacus muntjak

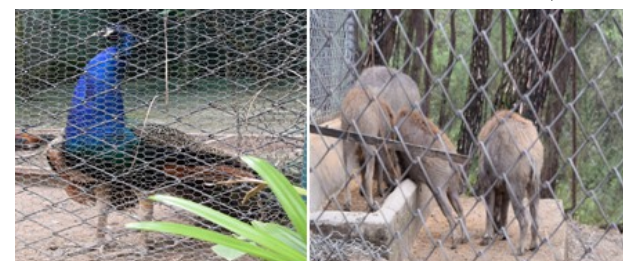

Pavo cristatus

Sus scrofa

Figure 3. Photographs of Fauna recorded in Dhauladhar Nature Park Gopalpur in western Himalayan region, $\mathrm{Hi}_{-}$ machal Pradesh (India) 
survey was carried out in the month of April, 2015.

\section{RESULTS AND DISCUSSION}

During the course of investigation 9 mammals viz., Asiatic lion (Panthera leo persica), common leopard (Panthera pardus), leopard cat (Prionailurus bengalensis), Ghoral (Nemorhaedus goral), Barking deer (Muntiacus muntjak), Sambar (Cervus unicolor), Himalayan black bear (Selenarctos thibetonus), Indian Procupine (Hystrix indica), Wild boar (Sus scrofa); 02 Reptiles viz., Indian black turtle (Melanochelys trijuga) and Indian flap shell turtle (Lissemys punctata); 05 Pheasants viz., Red jungle fowl (Gallus gallus), Indian peafowl (Pavo cristatus), Kalij pheasant (Lophura leucomelanos), Cheer pheasant (Catreus wallichii) and
Bhutan grey peacock (Polyplectron bicalcaratum bakeri) and 04 Other Birds viz., Himalayan griffon (Gyps himalayensis), Black kites (Milvus migrans), African grey parrot (Psittacus erithacus) and Emu (Dromaius novaehallandiae) were found to have been kept in special enclosures made for these animals (Table 1 and Figure 3).

Birds are considered as an indicator of the good condition of the natural environment [9]. Also, a birds survey conducted during July, 2011 have revealed that 89 species of birds (probably in openness of nature's park) have been present in this park and 49 out of these were of special concerns under wild life protection Act [8]. Further studies are required to find out that how many types of Himalayan butterflies like

Table 1. List of fauna recorded at Dhauladhar Nature Park Gopalpur in northwestern Himalayan region, Himachal Pradesh.

\begin{tabular}{|c|c|c|c|c|c|c|c|}
\hline Sr. No. & Name of Species & Zoological Name & Male & Female & Others & Total & Family \\
\hline \multicolumn{8}{|c|}{ Mammals } \\
\hline 1 & Asiatic Lion & Panthera leo persica & $\infty$ & 01 & $\infty$ & 01 & Felidae \\
\hline 2 & Comanon Leopard & Panthera pardus & 05 & 07 & $\infty$ & 12 & Felidae \\
\hline 3 & Leopard Cat & Prionsilurusbengalensis & $\infty$ & $\infty$ & 01 & 01 & Felidae \\
\hline 4 & Himalayan Black Bear & Selensurctos thibetonus & 07 & 03 & $\infty$ & 10 & Ursidae \\
\hline 5 & Wild Boar / Pig & Sus scrofs & 04 & 08 & $\infty$ & 12 & Suidae \\
\hline 6 & Sambar & Cervus unicolor & 15 & 25 & 03 & 43 & Cervidae \\
\hline 7 & Barking Deer & Muntiacus muntjak & 12 & 30 & 07 & 49 & Cervidae \\
\hline 8 & Ghoral & Nemorhaedus gorsl & 04 & 02 & $\infty$ & 06 & Bovidae \\
\hline 9 & Indian Porcupine & Hystrix indica & 02 & $\infty$ & $\infty$ & 02 & Hystricidae \\
\hline \multicolumn{8}{|l|}{ Reptiles } \\
\hline \multirow[t]{2}{*}{1} & Indian & Melsnochelys trijuga & 01 & 03 & 01 & 05 & Geoenaydidat \\
\hline & Black Turtle & & & & & & \\
\hline 2 & Indian Flap Shell Turtle & Lissenys punctats & $\infty$ & $\infty$ & 02 & 02 & Trionychidat \\
\hline \multicolumn{8}{|c|}{ Pheasants } \\
\hline \multirow[t]{2}{*}{1} & Red & Gallusgallus & 08 & 10 & $\infty$ & 18 & Phasianidae \\
\hline & Jungle Fowl & & & & & & \\
\hline 2 & Indian Peafowl & Pavo cristatus & 02 & $\infty$ & $\infty$ & 02 & Phasianidae \\
\hline 3 & Kalij Pheasant & Lophura leucomelsnos & 02 & 05 & $\infty$ & 07 & Phasianidae \\
\hline 4 & Cheer Pheasant & Cutreus wallichii & 01 & $\infty$ & $\infty$ & 01 & Phasianidae \\
\hline 5 & Bhutan Grey Peacock & $\begin{array}{l}\text { Polyplectron } \\
\text { bskeri }\end{array}$ & 01 & 01 & $\infty$ & 02 & Phasianidae \\
\hline \multicolumn{8}{|c|}{ Other Birds } \\
\hline 1 & Himalayan Griffon & Gyps bimslayensis & $\infty$ & $\infty$ & 01 & 01 & Accipitridae \\
\hline 2 & Black Kites & Milvus migrans & $\infty$ & $\infty$ & 05 & 05 & Accipitridae \\
\hline \multirow[t]{2}{*}{3} & African & Psittacus erithacus & $\infty$ & $\infty$ & 01 & 01 & Psittacidae \\
\hline & Grey Parrot & & & & & & \\
\hline \multirow[t]{2}{*}{4} & Emus & Dromsius novachallandiae & 01 & 01 & 01 & 03 & Dromaiidae \\
\hline & & Total & 65 & 96 & 22 & 183 & \\
\hline
\end{tabular}


Table 2. List of flora recorded at Dhauladhar Nature Park Gopalpur in northwestern Himalayan region, Himachal Pradesh

\begin{tabular}{|c|c|c|c|c|}
\hline Sr. No. & Common Name & English Name & Botanical Name & Family \\
\hline 1 & Dhrit Kumari & Aloe & Aloe vera & Aloaceae \\
\hline 2 & Aam & Mango & Mangifera indica & Anacardiaceae \\
\hline 3 & Khajur & Date Palm & Phoenix acaulis & Arecaceae \\
\hline 4 & Swallow Wort & Swallow Wort & Cynanchum louiseae & Asclepiadaceae \\
\hline 5 & Arjun & Arjuna & Terminalia arjuna & Combretaceae \\
\hline 6 & Sal & Sal & Shorea rubusta & Dipterocarpaceae \\
\hline 7 & Tandu & Tandu & Diospyros malanoxylon & Ebenaceae \\
\hline 8 & Ohi & Albizia & Albizia stipulata & Fabaceae \\
\hline 9 & Talli & Shhisham & Dalbergia sisso & Fabaceae \\
\hline 10 & Dhak & Flame of Forest & Butea monosperma & Fabaceae \\
\hline 11 & Tohr & Maloo Creeper & Bauhinia vahlii & Fabaceae \\
\hline 12 & Bhera & Bedda nut tree & Terminalia belerica & Fabaceae \\
\hline 13 & Siris & East Indian Walnut & Albizzia lebbeck & Fabaceae \\
\hline 14 & Ban & Ban Oak & $\begin{array}{l}\text { Quercus } \\
\text { lercotrichophora }\end{array}$ & Fagaceae \\
\hline 15 & Tulsi & Tulsi & Ocimum sanctum & Lamiaceae \\
\hline 16 & Pyung & Beauty Berry & Callicarpa Americana & Lamiaceae \\
\hline 17 & Aanar & Pomegranate & Punica granatum & Lythraceae \\
\hline 18 & Golden Champa & Golden Champa & Michelia champaca & Magnoliaceae \\
\hline 19 & Toona & Red Cendra & Toona sinesis & Meliaceae \\
\hline 20 & Gular & Cluster Fig & Ficus glomerata & Moraceae \\
\hline 21 & Anjir & Fig & Ficus palmata & Moraceae \\
\hline 22 & Pipal & Sacred fig & Ficus religiosa & Moraceae \\
\hline 23 & Tramble & Tramble & Ficus almrata & Moraceae \\
\hline 24 & Bargad & Banyan Tree & Ficus benghalensis & Moraceae \\
\hline 25 & Jamun & Black Plum & Syzygium cumini & Myrtaceae \\
\hline 26 & Bottle brush & Red Bottle Brush & Callistemon lancelatus & Myrtaceae \\
\hline 27 & Jatun & Olive Tree & Olea europaea & Oleaceae \\
\hline 28 & Ambla & Ambla & Emblica officinalis & Euphorbiaceae \\
\hline 29 & Deodar & Deodar & Cedrus deodar & Pinaceae \\
\hline 30 & Chiel & Pine Tree & Pinus roxburghii & Pinaceae \\
\hline 31 & Bansh & Bamboo & Dendrocalamus strictus & Poaceae \\
\hline 32 & Kainth & Indian Wild Pear & Pyrus pashia & Rosacae \\
\hline 33 & Silver Oak & Silver Oak & Grevillea robusta & Proteaceae \\
\hline 34 & Naspati & Pear & Pyrus sinensis & Rosacae \\
\hline 35 & Ber & Jujube & Ziziphus jujuba & Rhamnaceae \\
\hline 36 & Kadam & Kadam & Anthocephalus chinensis & Rubiaceae \\
\hline 37 & Beal & Bengal quince & Aegle marmelos & Rutaceae \\
\hline 38 & Katai & Ramontchi & Flacourtia indica & Salicaceae \\
\hline 39 & Indian Willow & Indian Willow & Salix tetrasperma & Salicaceae \\
\hline 40 & Paplar & Himalayan Poplar & Populus ciliata & Salicaceae \\
\hline 41 & Ritha & Soap Berry & Sapindus mukorossi & Sapindaceae \\
\hline 42 & Maulsari & Spanish cherryi & Mimusops elengi & Sapotaceae \\
\hline 43 & Angur & Grape & Vitis vinifera & Vitaceae \\
\hline 44 & Kher & Cutch tree & Acacia catechu & Mimosaceae \\
\hline
\end{tabular}

Junonia almanac, Torucus nara, Caprona alida, Ixias marianne, Danaus genutia, Moduza procris, Leptotes plinius, Catopsilia pyranthe, Danaus genutia, Euthalia nais, Lycaena phlaeas, Polyura athamas, Actolepis puspa, Vanessa cardui, Phalanta athamas, Dichorrhagia nesimachus, Kallima inachus, Neptis hylas, Parantica sita, Papilio demolues etc. have made this park as their home. Provisions should also be made in the park for keeping of Himalayan snakes like Asian cobra (Naja oxina), Russell's viper (Daboia russelli), Common krait (Bungarus caeruleus), Saw scaled viper (Echis carinatus), Spectacled cobra (Naja naja), Himalayan pit viper (Gloydius himalaynus), Himalayan mountain keelback (Amphiesma platyceps), Common cat snake (Boiga trigonata) etc.

Plant relative abundances typically vary greatly among species in a community [3,10-12]. The plants species in nature's park were represented by family Aloaceae [Aloe], Anacardiaceae [Mango], Arecaceae [Date palm], Asclepiadaceae [Swallow Wort], Combretaceae [Arjuna], Dipterocarpaceae [Sal], Ebenaceae [Tandu], Fabaceae [Albizia, Shhesham], Fagaceae [Ban oak], Lamiaceae [Tulsi, Beauty Berry], Lythraceae [Pomegranate], Magnoliaceae [Golden Champa], Meliaceae [Red Cendra], Moraceae [Cluster fig, Fig], Myrtaceae [Black plum and Red bottle brush], Oleaceae [Olive tree], Euphorbiaceae [Ambla], Pinaceae [Deodar and Pine tree], Poaceae [Bamboo], Rosacae [Indian wild pear], Proteaceae [Silver oak], Rhamnaceae [Jujube, Pear], Rubiaceae [Kadam], Rutaceae [Beal], Salicaceae [Indian willow, Poplar], Sapindaceae [Soap berry], Sapotaceae [Maulsari], Vitaceae [Grape] and Mimosaceae [Kher] (Table 2 and Figure 2).

\section{CONCLUSIONS}

In pristine time there was no dearth of natural resources, therefore man never felt like using these in a judicious manner. With the rapid growth of development during the last few centuries, there has been a lot of pressure on natural recourses including wildlife biodiversity. Moreover irrational use of these recourses, have further taken the situation to blinking point. If corrected measurers are not taken stringently right now, we will not be able to return this earth in the same manner in which we have inherited it from our forefathers. Therefore, studies on wildlife biodiversity become altogether more important and relevant to know our present status and progress in conservational efforts before it being lost forever. Also, it appears from present survey that Dhauladhar Nature's Park is playing a very important role in sensitizing and creating 
awareness among public, rescue and conservation of wild animals and by providing opportunity for research. Moreover, it has a lot of potential for further improvement as it could definitely play a very important role during the coming periods in conservation of some of the rare Himalayan species.

\section{ACKNOWLEDGMENT}

The author is highly thankful to Divisional Forest Officer, Wildlife Division Hamirpur, Distrcit Hamirpur Himachal Pradesh and Range Forest Officer, Dhauladhar Nature's Park Gopalpur District Kangra Himachal Pradesh for providing valuable information.

\section{REFERENCES}

1. Caswell H (1976) Community structure: a neutral model analysis. Ecol Mon 46: 327-354.

2. Bell G (2000) The distribution of abundance in neutral communities. Am Nat 155: 606-617.

3. Hubbel SP (2001) The unified neutral theory of biodiversity and biogeography. Princeton Univ. Press.

4. Diamond J (1989) Overview of recent extinctions, Conservation for the twenty-first century. 1989: 37-41.

5. Pimm, Stuart L, Gareth J, Russell, John LG, Thomas MB
(1955) The future of biodiversity. Science-AAAS-Weekly Paper Edition 269(5222): 347-349.

6. Sala OE, Chapin FS, Juan JA, Eric B, Janine B, Rodolfo D, Elisa-beth H (2000) Global biodiversity scenarios for the year 2100. Science. 287(5459): 1770-1774.

7. Vitousek PM, Harold AM, Jane L, Jerry MM (1997) Human domination of Earth's ecosystems. Science. 277(5325): 494-499.

8. Chandel S, Kumar V, Sharma BP, Patiyal R (2014) Bird Diversity of Dhauladhar Nature Park-Gopalpur, District Kangra, Himachal Pradesh. Asian Journal of Conservation Biology. 3(2014): 68-74.

9. Anil MNV, Kumari K, Watel SR (2014) Loss of Biodiversity and Conservation Strategies: An Outlook of Indian Scenario. Asian Journal of Conservation Biology 3(2014): 105-114.

10. Grime JP (1998) Benefits of plant diversity to ecosystems: immediate, filter and founder effects. J. Ecol 1998(86): 902-910.

11. Magurran AE (2004) Measuring biological diversity. Blackwell Publishing, Oxford, U.K.

12. Wilsey BJ, Polley HW (2004) Realistically low species evenness does not alter grassland species richness productivity relationships. Ecology 2004(85): 2693-2701. 